\title{
Antibody response to Haemophilus influenzae type-b conjugate vaccine in children and young adults with congenital asplenia or after undergoing splenectomy
}

\author{
B. Mikoluc $\cdot$ R. Motkowski $\cdot$ H. Käyhty • \\ E. Heropolitanska-Pliszka • B. Pietrucha • \\ E. Bernatowska
}

Received: 11 January 2011 / Accepted: 3 August 2011 /Published online: 27 August 2011

(C) The Author(s) 2011. This article is published with open access at Springerlink.com

\begin{abstract}
Absence of the spleen constitutes a risk of infection caused by encapsulated bacteria. The aim of our study was to determine the immune response to Haemophilus influenzae type-b (Hib) conjugate vaccine (HibCV) in asplenic individuals, considering the cause of asplenia, the age when splenectomy was carried out, and previous Hib vaccinations. Twenty asplenic patients, aged five to 25 years, were immunized with a single dose of HibCV. The specific antibody concentrations against $\mathrm{HibCV}$ were measured by enzyme-linked immunosorbent assay. Before vaccinations, the geometric mean antibody concentration (GMC) had an average value of $3.21 \mu \mathrm{g} / \mathrm{ml}$ and was comparable for all of the patients, regardless of the causes of asplenia. After vaccinations, the GMC was significantly higher, with an average of $6.78 \mu \mathrm{g} / \mathrm{ml}$. Further, 4.5 years
\end{abstract}

B. Mikoluc $(\bowtie) \cdot$ R. Motkowski

Department of Pediatrics and Developmental Disorders

in Children and Adolescents, Medical University of Bialystok,

17 Waszyngtona Str.,

15-224 Bialystok, Poland

e-mail: bozenam@mp.pl

\section{H. Käyhty}

Department of Vaccination and Immune Protection,

National Institute for Health and Welfare,

Mannerheimintie 166,

Helsinki, Finland

e-mail: helena.kayhty@thl.fi

E. Heropolitanska-Pliszka • B. Pietrucha $\cdot$ E. Bernatowska

Department of Immunology,

The Children's Memorial Health Institute,

20 Av. Dzieci Polskich,

04-736 Warsaw, Poland

E. Bernatowska

e-mail: bernatowskae@yahoo.com after vaccinations, the GMC was comparable to that of previously unvaccinated children. Moreover, 17/20 patients had GMC $\geq 1.0 \mu \mathrm{g} / \mathrm{ml}$, which included all of the children with congenital asplenia, children splenectomized before the age of six years, and only $57 \%$ of children splenectomized after that age. HibCV gives asplenic patients long-term protection. Hence, HibCV should be administered regardless of previous vaccinations and time from splenectomy, even if antibody evaluation is not available.

\section{Introduction}

Before the introduction of Haemophilus influenzae type-b (Hib) vaccine in national immunization programs, Hib was a common cause of invasive bacterial diseases and pneumonia in children under two years of age [1-4]. In older children, invasive Hib disease occurs less frequently; however, it has often been a disease of individuals with immune system dysfunction. An important high-risk group contracting invasive diseases caused by encapsulated bacteria (Streptococcus pneumoniae, Hib, and Neisseria meningitidis) comprises patients with congenital or acquired asplenia and humoral deficiencies [5-7]. This is why vaccination against $\mathrm{Hib}$, together with immunoprophylaxis against pneumococcal and meningococcal invasive infections, is highly recommended in this group of patients $[8,9]$.

Although the introduction of Hib conjugate vaccines (HibCVs) in the 1990s fundamentally altered the epidemiology of the Hib disease, it is good to remember that infections caused by encapsulated bacteria may be observed in asplenic individuals of any age, even many years after splenectomy [10]. 
Previous information on the immune response of asplenic patients to HibCV is scarce and outdated [11, 12]. The aim of our study was to determine the immune response to $\mathrm{HibCV}$ in asplenic children and young adults, considering the cause of asplenia, the age when splenectomy was carried out, and previous Hib vaccinations.

\section{Materials and methods}

\section{Patients}

Twenty asplenic patients, aged five to 25 years (mean: 14.7 years), under the medical care of the Department of Immunology at the Children's Memorial Health Institute in Warsaw, Poland (http://www.immunologia.czd.pl), were immunized with a single dose of HibCV (ActHIB, Sanofi Pasteur). The study group consisted of 16 postsplenectomy patients, three patients with congenital asplenia, and one patient with spherocytosis. The results of one patient with spherocytosis, who had been observed to have functional asplenia since birth, were combined with the results of patients with congenital asplenia. The main reasons for splenectomy were abdominal trauma (ten patients), cyst in the spleen (four patients), portal hypertension, and pancreatic tumor (one patient each). Splenectomy had been conducted in nine children before the age of six years, and in the remaining patients after the age of six years.

Thirteen patients had been vaccinated against Hib before taking part in the study (one child was vaccinated in infancy, and the remainder with one dose after the second year of life). This vaccination had been administered, on average, 4.5 years (ranging from one to seven years) before our test.

The patients were included in our study on the basis of their medical history and physical examination, and they were found to be in good health at the time of vaccination. The test was approved by the Bioethics Committee at the Children's Memorial Health Institute, Warsaw, Poland. Written informed consent was obtained from the patients, their parents, or their guardians.

\section{Methods}

Blood samples were collected just before and one month after a single dose of HibCV. No other vaccines were given during the study. The patients were observed for local and systemic adverse events for a period of $30 \mathrm{~min}$ after vaccination.

The specific Hib antibody concentrations were measured by enzyme-linked immunosorbent assay at the National Institute for Health and Welfare, Helsinki, Finland [13]. Antibody levels greater than 0.15 and $1.0 \mu \mathrm{g} / \mathrm{ml}$ are the minimum protective and the long-term protective concentrations, respectively $[14,15]$.

\section{Statistics}

For the quantitative variables, the geometric mean and 95\% confidence intervals were calculated, whereas for the qualitative variables, the number of patients and percentage distribution were calculated. The comparison between the groups was carried out by the Mann-Whitney $U$-test. For dependent variables, the Wilcoxon test was used. For the calculation, a significance level of $p<0.05$ was assumed as being statistically significant. The data was processed by the Polish version of Statistica 6.0.

\section{Results}

\section{Before vaccination}

In general, before vaccination, the patients had relatively high antibody concentrations (range: $\leq 0.15$ to $92.7 \mu \mathrm{g} / \mathrm{ml}$; geometric mean antibody concentration [GMC]: $3.21 \mu \mathrm{g} / \mathrm{ml}$ ). Concentrations of $\geq 0.15 \mu \mathrm{g} / \mathrm{ml}$ and $\geq 1.0 \mu \mathrm{g} / \mathrm{ml}$ were reached by 17 and 14 patients, respectively (out of 20 each; Table 1)

Thirteen children had been vaccinated against Hib one to seven years earlier (mean: 4.5 years), according to the recommended immunization schedule proposed by the Advisory Committee on Immunization Practices (ACIP) and other expert committees. Their GMC 4.5 years after vaccination did not show a statistically significant difference with reference to the concentrations of previously unvaccinated children $(p=0.75)$. The proportion of those patients who had concentrations $\geq 1.0 \mu \mathrm{g} / \mathrm{ml}$ was similar regardless of their previous vaccination history $(69.2 \%$ versus $71.4 \%$ ). Interestingly, the three patients who had GMC $\leq 0.15 \mu \mathrm{g} / \mathrm{ml}$ had been immunized previously.

All four children with congenital asplenia and spherocytosis, in addition to 10 of the $16(62.5 \%)$ splenectomized children, had antibody concentrations $\geq 1.0 \mu \mathrm{g} / \mathrm{ml}$ before vaccination. No statistically significant differences were found between the GMC levels of these two groups of patients $(p=0.68)$.

Our patients were divided into two groups on the basis of the age when splenectomy was conducted. No statistically significant differences were detected in the antibody concentrations before vaccinations between the group containing children with congenital asplenia or those splenectomized before the sixth year of life and the group of patients who had splenectomy after the age of six years ( $p=0.43$ ), although there was a tendency for lower concentrations in the group that had been splenectomized after the 
Table 1 Concentrations of antibodies and protection levels against Haemophilus influenzae type-b (Hib) in the study group before and after vaccination with Hib conjugate vaccine (HibCV)

\begin{tabular}{|c|c|c|c|c|c|}
\hline \multirow[t]{2}{*}{ Study group } & \multirow{2}{*}{$\begin{array}{l}\text { Before or after } \\
\text { HibCV vaccination }\end{array}$} & \multicolumn{2}{|c|}{ Antibody concentration $(\mu \mathrm{g} / \mathrm{ml})$} & \multirow[t]{2}{*}{$>1 \mu \mathrm{g} / \mathrm{ml}(\%)$} & \multirow[t]{2}{*}{$>0.15 \mu \mathrm{g} / \mathrm{ml}(\%)$} \\
\hline & & GMC $(95 \% \mathrm{CI})$ & $p$-value* & & \\
\hline \multirow[t]{2}{*}{ All patients $(n=20)$} & Before & $3.21(1.31-7.86)$ & 0.01 & 70.0 & 85.0 \\
\hline & After & $6.78(3.15-14.62)$ & & 85.0 & 100.0 \\
\hline \multirow[t]{2}{*}{ Previously vaccinated with Hib $(n=13)$} & Before & $2.69(0.82-8.80)$ & 0.01 & 69.2 & 76.9 \\
\hline & After & $6.52(2.57-16.52)$ & & 84.6 & 100.0 \\
\hline \multirow[t]{2}{*}{ Previously not vaccinated with $\mathrm{Hib}(n=7)$} & Before & $4.440 .74-26.67)$ & 0.01 & 71.4 & 100.0 \\
\hline & After & $7.30(1.21-44.03)$ & & 85.7 & 100.0 \\
\hline \multirow[t]{2}{*}{ Congenital asplenia $(n=4)$} & Before & $5.47(0.25-117.4)$ & 0.07 & 100.0 & 100.0 \\
\hline & After & $7.81(0.63-131.3)$ & & 100.0 & 100.0 \\
\hline \multirow[t]{2}{*}{ Splenectomy for other reasons $(n=16)$} & Before & $2.81(0.99-7.94)$ & 0.01 & 62.5 & 81.3 \\
\hline & After & $6.55(2.70-15.91)$ & & 81.3 & 100.0 \\
\hline \multirow{2}{*}{$\begin{array}{l}\text { Splenectomized before the age of six years } \\
(n=9) \text { or with congenital asplenia }(n=4)\end{array}$} & Before & $4.10(1.2-13.56)$ & 0.01 & 76.9 & 84.6 \\
\hline & After & $8.30(3.69-18.64)$ & & 100.0 & 100.0 \\
\hline \multirow[t]{2}{*}{ Splenectomized after the age of six years $(n=7)$} & Before & $2.03(0.37-11.26)$ & 0.01 & 57.1 & 85.7 \\
\hline & After & $4.67(0.63-34.50)$ & & 57.1 & 100.0 \\
\hline
\end{tabular}

GMC: geometric mean antibody concentration; $\mathrm{CI}$ : confidence interval

*Wilcoxon signed-rank test

age of six years. Antibody concentrations $\leq 1.0 \mu \mathrm{g} / \mathrm{ml}$ were found in $3 / 13(23.1 \%)$ of the patients splenectomized at ages $<6$ years and in $3 / 7(42.9 \%)$ of those splenectomized at ages $>6$ years.

\section{After vaccination}

No local or systemic adverse events were observed after the vaccination.

In the entire group of 20 patients, the GMC was $6.78 \mu \mathrm{g} / \mathrm{ml}$ (range: $0.4-107.58 \mu \mathrm{g} / \mathrm{ml}$ ) after vaccination. The increase was modest but statistically significant, as judged by the Wilcoxon signed-rank test $(p<0.01$; Table 1$)$. In total, five patients showed a greater-than-two-fold increase in antibody concentration. All patients had an antibody concentration $\geq 0.15 \mu \mathrm{g} / \mathrm{ml}$, and $17 / 20$ had values $\geq 1 \mu \mathrm{g} / \mathrm{ml}$ (Table 1, Fig. 1).

The GMC in the group vaccinated previously did not show any difference compared to the group not vaccinated before $(p=1.0)$; however, the antibody concentrations were higher after vaccination than before vaccination in both groups of patients $(p<0.01)$. All of the three patients who had levels of $\leq 0.15 \mu \mathrm{g} / \mathrm{ml}$ before immunization, in addition to being immunized previously, had an increase in their antibody concentration after vaccination. Concentration level $\geq 1.0 \mu \mathrm{g} / \mathrm{ml}$ was reached in $6 / 7$ and $11 / 13$ patients who had not been and had been previously vaccinated, respectively. The GMC in the group of 16 splenectomized children showed a statistically significant increase $(p<0.01)$,

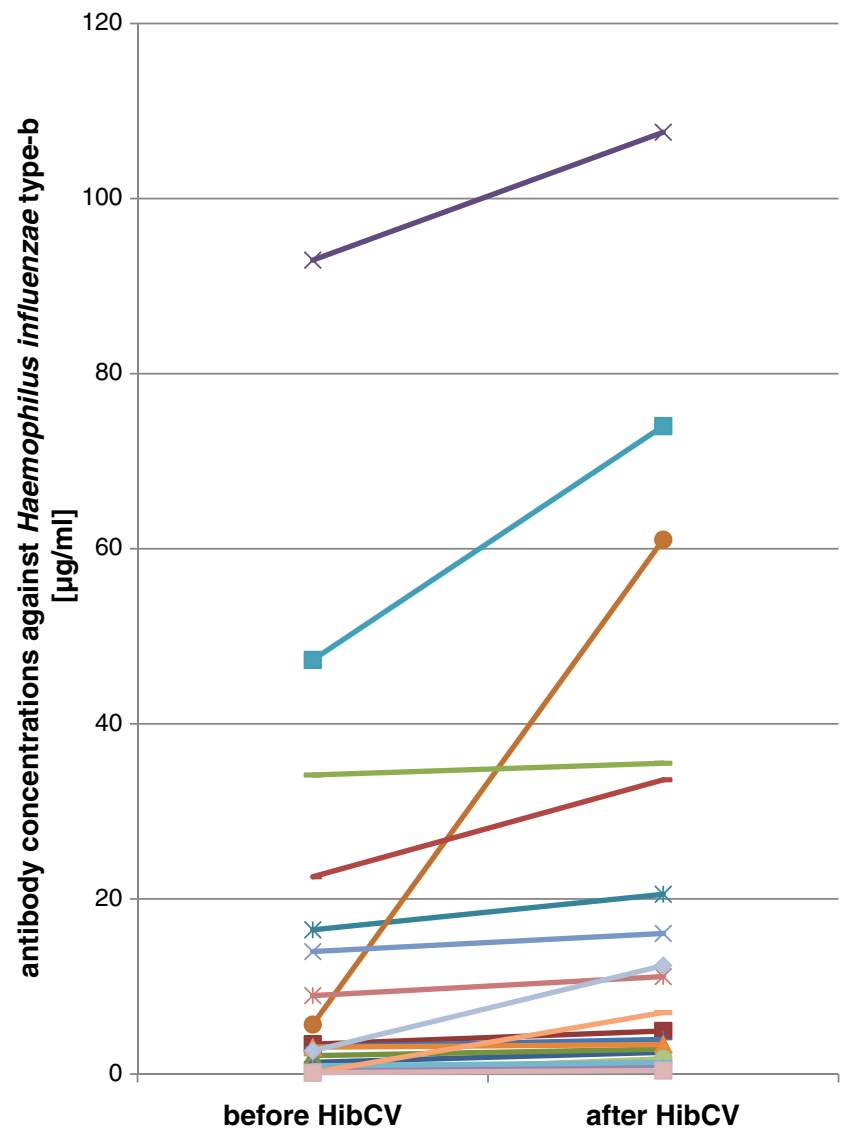

Fig. 1 Specific antibody concentrations against Haemophilus influenzae type-b (Hib) before and one month after Hib conjugate vaccine (HibCV) administration 
whereas in the group of four patients with congenital asplenia, the difference remained at the border of statistical significance $(p=0.07)$. There was no difference in antibody concentrations after vaccination in these two groups $(p=0.96)$. All four children with congenital asplenia had $\geq 1.0 \mu \mathrm{g} / \mathrm{ml}$ of antibodies both before and after vaccination. In the case of splenectomized children, the percentage of patients with $\geq 1.0 \mu \mathrm{g} / \mathrm{ml}$ of antibodies increased from $62.5 \%$ to $81.3 \%$.

A statistically significant increase was observed in the postvaccination antibody concentrations in the group of children with congenital asplenia or splenectomized before the sixth year of life and in the patients who underwent splenectomy after the age of six years $(p<0.01)$; moreover, the postvaccination antibody concentrations were similar $(p=0.53)$. All 13 children either with congenital asplenia or who were splenectomized before the age of six years had an antibody concentration $\geq 1.0 \mu \mathrm{g} / \mathrm{ml}$ after vaccination, whereas in the group of seven children splenectomized after the sixth year of life, the proportion was 4: 7.

\section{Discussion}

HibCV has been confirmed to be effective for healthy children [2, 16, 17]. Our research shows that HibCV is immunogenic in asplenic children and young adults; however, the measured immune response is only modest. One reason for the modest immune response can be that the concentrations of antibodies against Hib were relatively high even before vaccination, in both previously vaccinated and unvaccinated patients, probably due to the circulation of Hib in our population and the lack of compulsory Hib vaccination before 2007 in the Polish immunization schedule. Another possible reason is cross-reactivity from other bacteria [18].

Even if the response to Hib vaccination was only modest, it increased the proportion of patients with supposed protective concentrations, so that all had levels $>0.15 \mu \mathrm{g} / \mathrm{ml}$, and only three patients had levels $<1.0 \mu \mathrm{g} / \mathrm{ml}$. This increase of antibody concentration was observed independently of the previous Hib vaccinations. All of the four patients with congenital asplenia or spherocytosis already had high antibody concentrations before vaccination (range: $1.34-92.97 \mu \mathrm{g} / \mathrm{ml}$ ) and did not have an increase afterwards (Table 1), whereas many patients with splenectomy clearly benefited from the vaccination (Table 1), especially those with low antibody concentrations prevaccination (Fig. 1).

Opinion-making groups (World Health Organization; American Academy of Pediatrics; and immunization programs in countries of the European Union) recommend Hib vaccination for healthy children before the age of six years [19-21], as the age of the patient may be the basic factor influencing vaccine efficacy. In our study, a considerable postvaccination increase of antibody concentrations was observed in patients splenectomized before and after the age of six years. In the group of seven patients splenectomized after the sixth year of life, a subgroup of three children had concentrations $<1.0 \mu \mathrm{g} / \mathrm{ml}$ before vaccination, which remained at the same level after vaccination, whereas all those who were splenectomized before six years of age or had congenital asplenia showed antibody levels $>1.0 \mu \mathrm{g} / \mathrm{ml}$ after vaccination. Thus, our data suggest lower vaccine efficacy for children splenectomized after the age of six years.

It is also worth noting that the mean antibody concentrations in the pre- and postvaccination sera of patients vaccinated against Hib (on average, 4.5 years previously) were similar to those of patients who had not received HibCV before entering this study. In fact, all of the patients who had levels $\leq 0.15 \mu \mathrm{g} / \mathrm{ml}$ before vaccination had undergone vaccination previously. This suggests that immunization with HibCV might not offer persistent protection in this patient group and that vaccination later in life, regardless of previous vaccination status, would be useful.

Regardless of whether the children had previously been vaccinated or not, approximately $30 \%$ of the analyzed patients did not possess antibodies $>1.0 \mu \mathrm{g} / \mathrm{ml}$ and might potentially have been susceptible to invasive infection with Haemophilus influenzae. In an unmatched case-control study, McVernon et al. showed that the GMCs of convalescent Hib antibodies were comparable between immunized and unimmunized children, using both raw and adjusted data [22]. The GMC assessed after the vaccinations in both of these groups was statistically higher than that before the vaccinations, and the seroprotection level was $85 \%$. Our study indicates that, in asplenic patients, a subsequent vaccination, regardless of whether there had been previous vaccinations or not, is immunogenic.

In the patients previously vaccinated against Hib, reimmunization increased the antibody concentration and the level of seroprotection. Therefore, an additional dose of Hib vaccine should be administered to those asplenic patients whose postvaccination antibody concentration is below $1.0 \mu \mathrm{g} / \mathrm{ml}$. Consequently, a decision as to whether to revaccinate should be taken individually for each patient, ideally after assessing the patient's antibody concentration.

However, considering the low reactogenicity of $\mathrm{HibCV}$ [17] and the lack of access to the assessment of postvaccination antibodies, our study suggests that, regardless of the history of vaccinations against Hib, revaccination increases antibody titers, thus, providing protection. Revaccination with $\mathrm{Hib}$ is not recommended for asplenic individuals at present [5]. Our results indicate that, in the case of asplenic patients, a previously administered vaccine against Hib does not ensure a long-lasting protective level 
of antibodies, suggesting a need for revaccination with $\mathrm{HibCV}$ in the group of asplenic patients, despite the routine immunoprophylaxis of Hib in infancy.

\section{Conclusion}

Haemophilus influenzae type-b (Hib) conjugate vaccine (HibCV) increases antibody concentrations in asplenic patients, and most of these patients have antibody levels greater than $1.0 \mu \mathrm{g} / \mathrm{ml}$ after vaccination. Therefore, HibCV should be administered regardless of previous vaccinations and the time that has elapsed after splenectomy, even if antibody evaluation is not available.

Acknowledgments We thank Bozena Kusmirek and Leena Saarinen for the excellent laboratory support and antibody determinations.

Conflict of interest The authors declare that they have no conflict of interest.

Open Access This article is distributed under the terms of the Creative Commons Attribution Noncommercial License which permits any noncommercial use, distribution, and reproduction in any medium, provided the original author(s) and source are credited.

\section{References}

1. Ellis RW, Granoff DM (eds) (1994) Development and clinical uses of haemophilus $b$ conjugate vaccines, vol XVIII. Infectious disease and therapy. M. Dekker, New York

2. Eskola J, Käyhty H, Takala AK, Peltola H, Rönnberg PR, Kela E, Pekkanen E, McVerry PH, Mäkelä PH (1990) A randomized, prospective field trial of a conjugate vaccine in the protection of infants and young children against invasive Haemophilus influenzae type b disease. N Engl J Med 323(20):1381-1387

3. Steinhoff MC (1997) Haemophilus influenzae type b infections are preventable everywhere. Lancet 349(9060):1186-1187

4. Vadheim CM, Greenberg DP, Partridge S, Jing J, Ward JI (1993) Effectiveness and safety of an Haemophilus influenzae type $\mathrm{b}$ conjugate vaccine (PRP-T) in young infants. Kaiser-UCLA Vaccine Study Group. Pediatrics 92(2):272-279

5. Castagnola E, Fioredda F (2003) Prevention of life-threatening infections due to encapsulated bacteria in children with hyposplenia or asplenia: a brief review of current recommendations for practical purposes. Eur J Haematol 71(5):319-326

6. Davidson RN, Wall RA (2001) Prevention and management of infections in patients without a spleen. Clin Microbiol Infect 7 (12):657-660

7. Mourtzoukou EG, Pappas G, Peppas G, Falagas ME (2008) Vaccination of asplenic or hyposplenic adults. Br J Surg 95(3):273-280
8. Davies JM, Barnes R, Milligan D; British Committee for Standards in Haematology. Working Party of the Haematology/Oncology Task Force (2002) Update of guidelines for the prevention and treatment of infection in patients with an absent or dysfunctional spleen. Clin Med 2(5):440-443

9. Kroger AT, Atkinson WL, Marcuse EK, Pickering LK; Advisory Committee on Immunization Practices (ACIP) Centers for Disease Control and Prevention (CDC) (2006) General recommendations on immunization: recommendations of the Advisory Committee on Immunization Practices (ACIP). MMWR Recomm Rep 55 (RR-15):1-48

10. Cullingford GL, Watkins DN, Watts AD, Mallon DF (1991) Severe late postsplenectomy infection. Br J Surg 78(6):716-721

11. Cimaz R, Mensi C, D’Angelo E, Fantola E, Milone V, Biasio LR, Carnelli V, Zanetti AR (2001) Safety and immunogenicity of a conjugate vaccine against Haemophilus influenzae type $\mathrm{b}$ in splenectomized and nonsplenectomized patients with Cooley anemia. J Infect Dis 183(12):1819-1821

12. Konradsen HB, Rasmussen C, Ejstrud P, Hansen JB (1997) Antibody levels against Streptococcus pneumoniae and Haemophilus influenzae type $\mathrm{b}$ in a population of splenectomized individuals with varying vaccination status. Epidemiol Infect 119 (2):167-174

13. Mäkelä PH, Käyhty H, Leino T, Auranen K, Peltola H, Ekström N, Eskola J (2003) Long-term persistence of immunity after immunisation with Haemophilus influenzae type $\mathrm{b}$ conjugate vaccine. Vaccine 22(2):287-292

14. Käyhty H, Peltola H, Karanko V, Mäkelä PH (1983) The protective level of serum antibodies to the capsular polysaccharide of Haemophilus influenzae type b. J Infect Dis 147(6):1100

15. Ward J, Lieberman JM, Cochi S (1994) Haemophilus influenzae. In: Plotkin SA, Mortimer EA (eds) Vaccines, 2nd edn. WB Saunders, Philadelphia, pp 337-386

16. Eskola J, Peltola H, Takala AK, Käyhty H, Hakulinen M, Karanko V, Kela E, Rekola P, Rönnberg PR, Samuelson JS, Gordon LK, Mäkelä H (1987) Efficacy of Haemophilus influenzae type b polysaccharide-diphtheria toxoid conjugate vaccine in infancy. $\mathrm{N}$ Engl J Med 317(12):717-722

17. Swingler G, Fransman D, Hussey G (2007) Conjugate vaccines for preventing Haemophilus influenzae type B infections. Cochrane Database Syst Rev (2):CD001729

18. Schiøtz PO, Høiby N, Hertz JB (1979) Cross-reactions between Haemophilus influenzae and nineteen other bacterial species. Acta Pathol Microbiol Scand B 87(6):337-344

19. American Academy of Pediatrics (1991) AAP updates Hib vaccine recommendations. Bol Asoc Med P R 83(4):168-169

20. World Health Organization (WHO) (2006) WHO position paper on Haemophilus influenzae type b conjugate vaccines. (Replaces WHO position paper on Hib vaccines previously published in the Weekly Epidemiological Record. Wkly Epidemiol Rec 81 (47):445-452

21. Centers for Disease Control and Prevention (CDC) (2009) Updated recommendations for use of Haemophilus influenzae type $b$ (Hib) vaccine: reinstatement of the booster dose at ages 12-15 months. MMWR Morb Mortal Wkly Rep 58(24):673-674

22. McVernon J, Johnson PD, Pollard AJ, Slack MP, Moxon ER (2003) Immunologic memory in Haemophilus influenzae type b conjugate vaccine failure. Arch Dis Child 88(5):379-383 